\title{
SCREENING OF PASSIFLORA SPECIES FOR REACTION TO COWPEA APHID-BORNE MOSAIC VIRUS REVEALS AN IMMUNE WILD SPECIES
}

\author{
Scheila da Conceição Maciel1'; Daniel Hiroshi Nakano²; Jorge Alberto Marques Rezende ${ }^{3 *}$; \\ Maria Lúcia Carneiro Vieira ${ }^{4}$ \\ ${ }^{1}$ USP/ESALQ - Programa de Pós-Graduação em Fitopatologia. \\ ${ }^{2} U S P / E S A L Q$ - Graduando em Agronomia. \\ ${ }^{3}$ USP/ESALQ - Depto. de Entomologia, Fitopatologia e Zoologia Agrícola, C.P. 09 - 13418-900 - Piracicaba, SP - \\ Brasil. \\ ${ }^{4}$ USP/ESALQ - Depto. de Genética, C.P. 09 - 13418-900 - Piracicaba, SP - Brasil. \\ *Corresponding author <jamrezen@esalq.usp.br>
}

\begin{abstract}
Cowpea aphid-borne mosaic virus (CABMV) is a potyvirus that causes the most serious virus disease of passion fruit crops in Brazil. It is transmitted by several species of aphids in a nonpersistent, non-circulative manner. The reaction of 16 species of Passiflora to infection by mechanical inoculation with four Brazilian isolates of CABMV was evaluated under greenhouse conditions. Only $P$. suberosa, a wild species, was resistant to infection by all virus isolates, in two independent assays. $P$. suberosa grafted onto infected $P$. edulis f. flavicarpa did not develop symptoms; neither was the virus detected by RT-PCR in the upper leaves, suggesting that this species is immune to CABMV.

Key words: Passifloraceae, potyvirus, resistance
\end{abstract}

\section{SELEÇÃO DE ESPÉCIES DE PASSIFLORA INOCULADAS COMO VÍRUS DO MOSAICO DO CAUPI REVELA A IMUNIDADE DE UMA ESPÉCIE SELVAGEM}

\begin{abstract}
RESUMO: O vírus do mosaico do caupi (Cowpea aphid-borne mosaic virus - CABMV) é um potyvirus que causa uma das mais importantes doenças do maracujazeiro no Brasil. O vírus é transmitido por diversas espécies de afídeos de maneira não persistente, não circulativa. A reação de 16 espécies de Passiflora à infecção com quatro isolados brasileiros do CABMV, por meio de inoculação mecânica foi avaliada em condições de casa-de-vegetação. Somente a espécie selvagem $P$. suberosa foi resistente à infecção com todos os isolados do CABMV, em dois ensaios independentes. Plantas de $P$. suberosa enxertadas em plantas de $P$. edulis f. flavicarpa infectadas com o CABMV também não desenvolveram sintomas da doença. O vírus também não foi detectado por RT-PCR nas folhas superiores das plantas, sugerindo que essa espécie é imune ao CABMV.

Palavras-chave: Passifloraceae, potyvirus, resistência
\end{abstract}

\section{INTRODUCTION}

Brazil is the world's largest producer of passion fruit, represented mainly by yellow passion fruit (Passiflora edulis f. flavicarpa) (97\%) and sweet passion fruit $(P$. alata) $(3 \%)$, with an estimated planted area of 36,576 ha, and a total annual yield of 491,619 t. (FNP, 2007).

Seven diseases caused by viruses have already been reported in passion fruit crops in Brazil. Among them, passion fruit woodiness is the most important, since it is widely disseminated across all the country's producing regions and causes significant yield dam- age (Gioria et al., 2000; Fisher et al., 2005). Since the disease was first detected in Brazil in the 1970's (Chagas et al., 1981), several reports have indicated that it is caused by Passion fruit woodiness virus (PWV) (Kitajima et al., 1986; Chagas et al., 1992; Fisher et al., 2005). However, studies based on the nucleotide sequence of the coat protein coding region of the virus genome clearly indicated that the disease is caused by a strain of Cowpea aphid-borne mosaic virus (CABMV) (Nascimento et al., 2006; Barros et al., 2007).

The CABMV is a species of the genus Potyvirus, family Potyviridae, which is naturally 
transmitted by several species of aphids, with a nonpersistent, non-circulative virus-vector relationship (Bock \& Conti, 1974; Fauquet et al., 2005; Fisher et al., 2005). On passion flower vines CABMV induces mosaic symptoms, accompanied by leaf malformation, blisters, a marked reduction in plant development, and woodiness in a variable percentage of fruits (Fisher et al., 2005; Nascimento et al., 2006).

Despite the fact that this virus disease has been recognized for a relatively long time in Brazil, there are no control alternatives (Novaes \& Rezende, 2003: Alfenas et al., 2005; Trevisan et al., 2006). The only practice adopted by producers is the regular renovation of the crop after the first harvests, when $100 \%$ of the plants become infected.

This study aims to evaluate the reaction of some Passiflora species and commercial populations of passion fruits to CABMV isolates collected from different regions of Brazil, in order to support resistance breeding programs.

\section{MATERIAL AND METHODS}

The species and commercial populations of Passiflora evaluated in the study are listed in Table 1.
The seeds and/or cuttings of these species/populations were obtained from the Instituto Agronômico de Campinas, SP, Universidade Estadual Paulista, Campus de Jaboticabal, SP, Escola Superior de Agricultura 'Luiz de Queiroz (ESALQ), Piracicaba, São Paulo state, Brazil, and Flora Brasil Ltda, Araguari, Minas Gerais state, Brazil.

Plant reaction to CABMV was evaluated under greenhouse conditions. Virus isolates from the states of Ceará (CABMV-CE), Pará (CABMV-PA), Rio de Janeiro (CABMV-RJ), and São Paulo (CABMV-SP) were used. The isolates were identified by RT-PCR analysis. Total RNA was extracted from infected tissue with Trizol Reagent (Invitrogen) according to manufacturer's recommendations, and then used for synthesis of cDNA fragments by RT-PCR using Superscript ${ }^{\circledR}$ III Reverse Polymerase and Taq DNA Polymerase (Invitrogen), according to manufacturer's recommendations. A pair of primers described by Trevisan et al. (2006), which flanks the capsid protein coding region, and amplifies a fragment of $850 \mathrm{bp}$, was used for RT-PCR. The thermocycler (MJ Research PTC 200) amplification profile was set to $94^{\circ} \mathrm{C}$ for $2 \mathrm{~min}$, followed by 35 cycles of $94^{\circ} \mathrm{C}$ for $45 \mathrm{~s}, 52^{\circ} \mathrm{C}$ for $1 \mathrm{~min}$ and $72^{\circ} \mathrm{C}$ for $1 \mathrm{~min}$, followed by a final elongation step at $72^{\circ} \mathrm{C} / 1 \mathrm{~min}$. Am-

Table 1 - Reaction of Passiflora species to four Cowpea aphid-borne mosaic virus (CABMV) isolates in two independent experiments, under greenhouse conditions.

\begin{tabular}{lcccc}
\hline \multirow{2}{*}{ Species/populations } & \multicolumn{3}{c}{ No. of infected plants/No. of inoculated plants* } \\
\cline { 2 - 5 } & CABMV-PA & CABMV-SP & CABMV-RJ & CABMV-CE \\
\hline P. alata & $6 / 10$ & $7 / 10$ & $10 / 10$ & $6 / 9$ \\
P. amethystina & $10 / 10$ & $10 / 10$ & $10 / 10$ & $9 / 10$ \\
P. caerulea & $10 / 10$ & $10 / 10$ & $10 / 10$ & $10 / 10$ \\
P. cincinatta & $8 / 10$ & $7 / 9$ & $10 / 10$ & $8 / 10$ \\
P. edulis f. flavicarpa - FB-100** & $5 / 5$ & $5 / 5$ & $4 / 5$ & $4 / 5$ \\
P. edulis f. flavicarpa- FB-200** & $4 / 5$ & $3 / 5$ & $5 / 5$ & $5 / 5$ \\
P. edulis f. flavicarpa - IAC-275** & $5 / 5$ & $5 / 5$ & $5 / 5$ & $5 / 5$ \\
P. edulis f. flavicarpa - IAC-277** & $4 / 5$ & $4 / 5$ & $3 / 5$ & $4 / 5$ \\
P. foetida & $10 / 10$ & $4 / 5 * *$ & $9 / 10$ & $10 / 10$ \\
P. giberti & $7 / 10$ & $9 / 10$ & $7 / 10$ & $7 / 10$ \\
P. laurifolia & $5 / 5 * *$ & $4 / 10$ & $2 / 5 * *$ & $10 / 10$ \\
P. maliformes & $8 / 10$ & $9 / 9$ & $8 / 9$ & $8 / 8$ \\
P. morifolia & $10 / 10$ & $5 / 5 * *$ & $9 / 10$ & $7 / 9$ \\
P. mucronata & $6 / 10$ & $3 / 10$ & $3 / 10$ & $4 / 10$ \\
P. nitida & $9 / 9$ & $9 / 9$ & $8 / 10$ & $9 / 10$ \\
P. quadrangularis & $8 / 10$ & $4 / 5$ & $8 / 10$ & $3 / 9$ \\
P. serrato-digitata & $7 / 10$ & $7 / 10$ & $8 / 10$ & $4 / 10$ \\
P. setacea** & $\mathrm{NT}$ & $1 / 5$ & $0 / 5$ & $3 / 5$ \\
P. suberosa & $0 / 10$ & $0 / 10$ & $0 / 10$ & $0 / 10$ \\
\hline S. & & & \\
\hline
\end{tabular}

*Sum of two independent tests. ${ }^{* *}$ Results from a single test. NT $=$ not tested 
plified cDNA fragments were visualized in $1 \%$ agarose gel stained with $0.5 \mu \mathrm{g} \mathrm{mL}^{-1}$ ethidium bromide, under UV light. A $1 \mathrm{~Kb}$ DNA ladder was used as a molecular weight standard. The virus isolates were maintained on P. edulis f. flavicarpa plants in the greenhouse. The Passiflora spp plantlets were obtained using aluminum pots containing a mixture of soil and organic matter. After seed germination and/or cuttings became rooted, plants were thinned to one or two per pot. Inocula of different CABMV isolates were prepared in $0.02 \mathrm{M}$ potassium phosphate buffer, $\mathrm{pH} 7.0$, containing $0.02 \mathrm{M}$ sodium sulfite. Each CABMV isolate was separately inoculated mechanically in groups of plants, at the $4-5$ leaf stage, from the various species/populations. Plant reaction was evaluated in two independent assays. Systemic symptoms on the leaves were recorded during a period of 30 to 60 days after inoculation. Infection was confirmed by Plate Trapped Antigen-ELISA (PTAELISA) (Mowat \& Dawson, 1987) using polyclonal antiserum against passion fruit strain of CABMV produced at the Plant Virology Laboratory, ESALQ, USP, Piracicaba, SP, and back inoculation to $P$. edulis $\mathrm{f}$. flavicarpa.

The immune reaction was evaluated by grafting branches from a healthy plant of the species under analysis onto $P$. edulis f. flavicarpa plants systemically infected with each CABMV isolate, separately. The controls consisted of healthy $P$. edulis $\mathrm{f}$. flavicarpa branches grafted onto infected rootstocks of the same species (top cleft grafting). Evaluations were performed at 60 and 90 days after development of young shoots, based on the presence of symptoms and by RT-PCR for the CABMV capsid protein coding region as described above.

\section{RESULTS AND DISCUSSION}

Fifteen of the 16 Passiflora species, including four commercial populations of $P$. edulis $\mathrm{f}$. flavicarpa (FB-100, FB-200, IAC-275, and IAC-277), were susceptible to CABMV isolates, showing foliar mosaic symptoms, leaf deformations and blisters, depending on the species (Table 1). The infection of all inoculated plants was confirmed by PTA-ELISA and by back inoculation tests to $P$. edulis f. flavicarpa plants. Interestingly, P. suberosa did not show symptoms when inoculated with all virus isolates in both tests. In addition, the virus was not detected by PTAELISA in leaves of the leader shoot of any of the $P$. suberosa plants, and the virus was not recovered by back inoculation to $P$. edulis f. flavicarpa, indicating that $P$. suberosa was in fact resistant to infection with the four isolates of CABMV (data not shown). This result corroborates the data obtained by Costa (1994), who reported the species as being apparently immune to a PWV isolate (which was probably a CABMV isolate) from the State of Pernambuco, Brazil.

The number of $P$. suberosa plants grown on $P$. edulis f. flavicarpa rootstocks infected with the four isolates of the virus was: $\mathrm{CABMV}-\mathrm{CE}=1$, CABMV-PA $=1$, CABMV-RJ $=2$, and CABMV-SP $=2$. Observations for over 90 days indicated that no $P$. suberosa plants showed infection symptoms (Figure 1), while all five $P$. edulis f. flavicarpa grafts (control) that developed on infected plants of the same species exhibited mosaic symptoms and leaf deformation. Lateral shoots from the rootstocks exhibited symptoms of the virus disease, indicating that the virus was present in the $P$. edulis f. flavicarpa plants. CABMV was not detected by RT-PCR from young leaves of $P$. suberosa plants developed on infected rootstocks but was detected in the controls (Figure 2). The fact that the virus was not detected in plants grafted onto infected plants is a strong indication that $P$. suberosa is immune to CABMV.

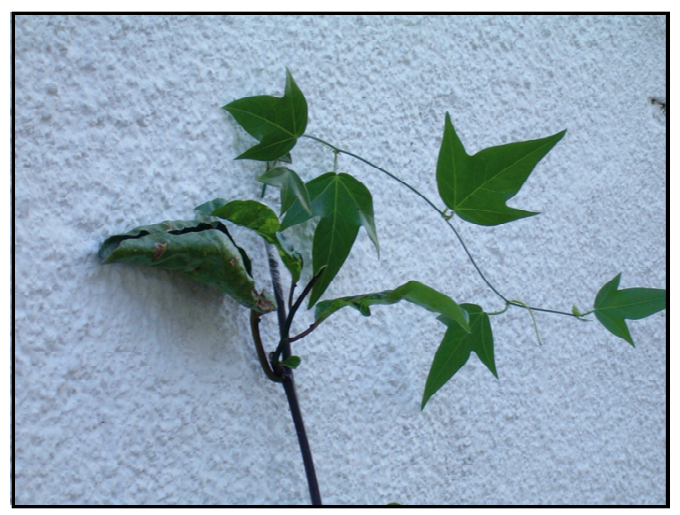

Figure 1 - Asymptomatic P. suberosa grafted onto CABMV-SPinfected $P$. edulis f. flavicarpa.

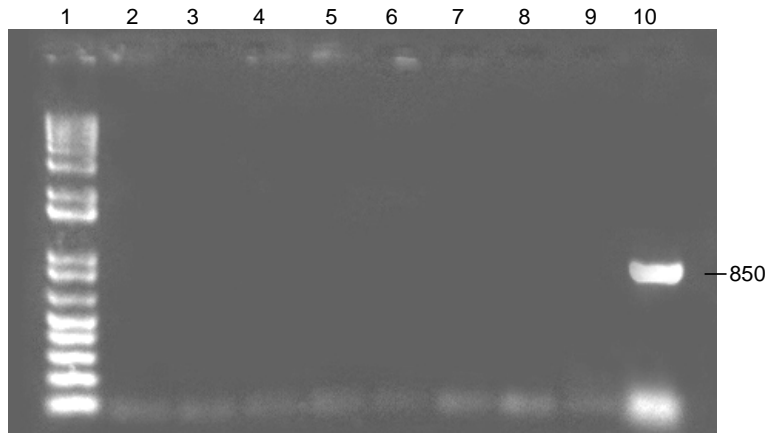

Figure 2 - RT-PCR analysis for detection of the CABMV capsid protein coding region. $1-1 \mathrm{~kb}$ molecular weight marker; 2 and $3-P$. suberosa grafted onto CABMVSP-infected $P$. e. f. flavicarpa; 4 and 5 - P. suberosa grafted onto CABMV-RJ-infected $P$. e. f. flavicarpa; 6 - P. suberosa grafted onto CABMV-CE-infected $P$. e. f. flavicarpa; 7 - P. suberosa grafted onto CABMVPA-infected $P$. e. f. flavicarpa; 8 - healthy $P$. suberosa, 9 - healthy P. e. f. flavicarpa; and $10-P$. e. f. flavicarpa grafted onto CABMV-SP-infected $P$. e. f. flavicarpa. 
In its reaction to other potyviruses, $P$. suberosa was also reported as resistant to Passiflora virus $\mathrm{Y}$ in Australia (Parry et al., 2004) and East Asian Passiflora virus in Japan (Iwai et al., 2006), but susceptible to Passion fruit ringspot virus in The Ivory Coast (De Wijs, 1974), Passion fruit mottle virus and PWV in Taiwan (Chang, 1992). The reaction of this species to PWV in Australia has been variable. Brunt et al. (1990) listed it as susceptible, whereas Parry et al. (2004) reported it as resistant. In Brazil, preliminary tests indicated that $P$. suberosa was susceptible to Passion fruit little leaf mosaic virus (Novaes et al., 2003), a begomovirus transmitted by Bemisia tabaci (data not published). P. suberosa was also cited as a source of resistance to the fungus Fusarium oxysporum f. sp. passiflorae, which causes fusarium wilt (Gardner, 1989).

P. suberosa is one of the species with greatest variability within the genus, with intra-specific variation in the diploid chromosome set, namely, $2 \mathrm{n}=12$, 24, and 36 chromosomes (Otoni et al., 1996). The plants used in this study are $2 \mathrm{n}=24$. The species $P$. edulis f. flavicarpa has $2 \mathrm{n}=18$. Although they belong to different subgenera i.e. Decaloba and Passiflora (Ulmer \& MacDougal, 2004), respectively, attempts at obtaining interspecific hybrids to allow transfer $P$. suberosa resistance/immunity to CABMV into cultivated passion fruit species must be encouraged, in order to address one of the most serious diseases that affects this important crop in Brazil.

\section{ACKNOWLEDGEMENTS}

This research was funded by FAPESP (Fundação de Amparo à Pesquisa do Estado de São Paulo). The authors would like to thank Dr. Hugo Kuniyuki (APTA, IAC, Campinas, SP) for his rigorous checking of the manuscript.

\section{REFERENCES}

ALFENAS, P.F.; BRAZ, A.S.K.; TORRES, L.B.; SANTANA, E.; NASCIMENTO, V.S.; CARVALHO, M.G.; OTONI, W.C.; ZERBINI, F.M. Transgenic passion fruit expressing RNA derived from Cowpea aphid-borne mosaic virus is resistant to passion fruit woodiness disease. Fitopatologia Brasileira, v.30, p.3338,2005 .

BARROS, D.R.; BESERRA, J.E.A.; ALFENAS-ZERBINI, P.; PIORIBEIRO, G.; ZERBINI, F.M. Complete genomic sequence of two isolates of Cowpea aphid-borne mosaic virus (CABMV) obtained from different hosts. Virus Review \& Research, v.12, p.238-239, 2007.

BOCK, K.R.; CONTI, M. Cowpea aphid-borne mosaic virus. Kew: CMI/AAB, 1974. 5p. (CMI/AAB Descriptions of Plant Viruses, 134).

BRUNT, A.; CRABTREE, K.; GIBBS, A. Viruses of tropical plants: descriptions and list from VIDE database. Wallingford: ACIAR, 1990. 707p.
CHAGAS, C.M.; KITAJIMA, E.W.; LIN, M.T.; GAMA, M.I.C.S.; YAMASHIRO, T. Grave moléstia em maracujá amarelo (Passiflora edulis f. flavicarpa) no Estado da Bahia, causado por um isolado do vírus do "woodiness" do maracujá. Fitopatologia Brasileira, v.6, p.259-268, 1981.

CHAGAS, C.M.; REZENDE, J.A.M.; COLARICCIO, A.; PIZA JR., C.T.; LOPES, L.C.; GALLETTI, S.R.; FERRARI, J.T.; BELLUZI, B.M. Ocorrência do endurecimento do fruto do maracujazeiro (VEFM) no Estado de São Paulo. Revista Brasileira de Fruticultura, v.14, p.187-190, 1992.

CHANG, C.A. Characterizarion and comparison of passion fruit mottle virus, a newly recognized potyvirus, with passion fruit woodiness virus. Phytopathology, v.82, p.1358-1363, 1992.

COSTA, A.F. Pesquisa e extensão com maracujá em Pernambuco. In: SÃO JOSÉ, A.R. (Ed.) Maracujá: produção e mercado. Vitória da Conquista: UESB, 1994. p.138-143.

DE WIJS, J.J. A virus causing ringspot of Passiflora edulis in the Ivory Coast. Annals of Applied Biology, v.77, p.33-40, 1974.

FAUQUET, C.M.; MAYO, M.A.; MANILOFF, J.; DESSELBERGER, U.; BALL, L.A. Virus taxonomy: classification and nomenclature of viruses. London: Elsevier Academic Press, 2005.1259p.

FISHER, I.H.; KIMATI, H.; REZENDE, J.A.M. Doenças do maracujazeiro. In: KIMATI, H.; AMORIM, L.; REZENDE, J.A.M.; BERGAMIN FILHO, A.; CAMARGO, L.E.A. (Ed.) Manual de fitopatologia: doenças das plantas cultivadas. Piracicaba: Agronômica Ceres, 2005. p.467-474.

FNP CONSUlTORIA \& COMÉRCIO. Agrianual 2007: anuário estatístico da agricultura brasileira. São Paulo: Argos Comunicação, 2007. p.387-394.

GARDNER, D.E. Pathogenecity of Fusarium oxysporium f. sp. passiflorae to banana poka and other Passiflora spp. in Hawaii. Plant Disease, v.73, p.476-478, 1989.

GIORIA, R.; BOSQUÊ, G.G.; REZENDE, J.A.M.; AMORIM, L.; KITAJIMA, E.W. Incidência de viroses de maracujazeiro na Alta Paulista - SP e danos causados pelo "Passionfruit woodiness virus". Fitopatologia Brasileira, v.25, p.182-189, 2000.

IWAI, H.; YAMASHITA, Y.; NISHI, N.; NAKAMURA, M. The potyvirus associated with the dappled fruit of Passiflora edulis in Kagoshima prefecture, Japan is the third strain of the proposed new species East Asian Passiflora virus (EAPV) phylogenetically distinguished from strains of Passion fruit woodiness virus. Archives of Virology, v.151, p.811-818, 2006.

KITAJIMA, E.W.; CHAGAS, C.W.; CRESTANI, O.A. Enfermidades de etiologia viral e associadas a organismos do tipo micoplasma em maracujazeiro no Brasil. Fitopatologia Brasileira, v.11, p.409-432, 1986.

MOWAT, W.P.; DAWSON, S. Detection of plant viruses by ELISA using crude sap extracts and unfractionated antisera. Journal of Virological Methods, v.15, p.233-247, 1987.

NASCIMENTO, A.V.S.; SANTANA, E.N.; BRAZ, A.S.K.; ALFENAS, P.F.; PIO-RIBEIRO, G.; ANDRADE, G.P.; CARVALHO, M.G.; ZERBINI, F.M. Cowpea aphid-borne mosaic virus (CABMV) is widespread in passionfruit in Brazil and causes passionfruit woodiness disease. Archives of Virology, v.151, p.1797-1809, 2006.

NOVAES, Q.S.; ASTUA, J.F.; YUKI, E.W.; KITAJIMA, E.W.; CAMARGO, L.E.A.; REZENDE, J.A.M. Partial characterization of a bipartite begomovirus infecting yellow passion flower in Brazil. Plant Pathology, v.52, p.648-654, 2003.

NOVAES, Q.S.; REZENDE, J.A.M. Selected mild strains of Passion fruit woodiness virus (PWV) fail to protect pre-immunized vines in Brazil. Scientia Agricola, v.60, p.699-708, 2003.

OTONI, W.C.; CASALI, V.W.D.; POWER, J.B.; DAVEY, M.R. Isolamento de protoplastos de mesófilo de P. suberosa L.: influência da idade das plantas matrizes. Revista Ceres, v.43, p.157-164, 1996. 
PARRY, J.N.; DAVIS, R.I.; THOMAS, J.E. Passiflora virus Y, a novel virus infecting Passiflora spp. in Australia and the Indonesian Province of Papua. Australasian Plant Pathology, v.33, p.423-427, 2004.

TREVISAN, F.; MENDES, B.M.J.; MACIEL, S.C.; VIEIRA, M.L.C.; MELETTI, L.M.M.; REZENDE, J.A.M. Resistance to Passion fruit woodiness virus in transgenic passionflower expressing the virus coat protein gene. Plant Disease, v.90, p.1026-1030, 2006 .
ULMER, T.; MacDOUGAL, J.M. Passiflora: passionflowers of the world. Cambridge: Timber Press, 2004. 430p.

Received April 23, 2008

Accepted November 14, 2008 